\title{
Thomas S. Popkewitz, ed. Rethinking the History of Education: Transnational Perspectives on Its Questions, Methods, and Knowledge
}

\author{
New York: Palgrave Macmillan, 2013. 251 pp.
}

\section{Kari Dehli}

University of Toronto/Ontario Institute for Studies in Education

In the opening sentence to the Preface to this collection the editor, Thomas S. Popkewitz, states that the book was written "to contribute to a dialogue between leading historians working in education outside of the United States and American historians of education" (xiii). As there are no Canadian contributors to the collection, readers of $H S E / R H E$ may ponder how to respond to this invitation, and whether they would place themselves in the first or second of these groups, or perhaps choose both or neither? Popkewitz wants to question the production, circulation, and effects of the terms and categories used and/or assumed by historians to name their subjects and objects. He is particularly critical of the positivism and provincialism that, in his view, characterizes education history in the United States, even in much of the history that aims to critique the inequalities and injustices of schooling. Therefore, the question of how and where "we" might position ourselves in relation to the categories that he fashions in his invitation to a dialogue is not a trivial one. I will return to it in this review's conclusion.

Popkewitz asserts a wish "to engage the history of education in a conversation by its questions, methods, and knowledge" (2), and at the same time to challenge orthodoxies in the history and historiography of education. For readers old enough to have attended the joint conference of CHEA/ACHÉ and the History of Education Society (US) in Toronto in 1996, these assertions have a familiar ring. The provocative questions that Popkewitz raises about historical orthodoxies in his preface and introduction will be of interest to many readers of this journal. In a prolific output of articles, papers, books, and edited and co-edited collections over several years, Popkewitz 
has posed similar challenges to curriculum scholars, sociologists and philosophers of education. While not foregrounded as explicitly here as in his other publications, Popkewitz has for many years worked with questions inspired by Foucault's archaeology of knowledge and his genealogies of power and the subject. ${ }^{1}$ Traversing sociology and history of schooling and curriculum, Popkewitz has previously written that his "concern with history is to understand how the current problems of schooling, defined as school reform, become constituted as they are."

One key feature of the collection reviewed here is its transnationality, both in terms of the location and empirical focus of the authors (Brazil-Turkey, China, Luxembourg, Mexico, Portugal, Switzerland, the United Kingdom and the United States) and in the perspectives they bring to bear on their topics. Thus, several chapters aim to complicate our understanding of the places, connections, and discourses that shaped educational thinking and practice in the past, and to trace the spaces and networks in which educators moved, worked, or wrote. Warde's chapter on relations between educators in Turkey and Brazil questions easy assumptions about the flow of ideas and influence, while Horlacher and Sobe reflect on how specificities of time and place complicate chronological accounts of change and comparison. Trohler's chapter provides an insightful interrogation of historians' relationship to the archive, and the ways in which its documents and objects are transformed into "data" that are made to "speak for themselves." I enjoyed reading that chapter alongside Zongjie Wu's contribution on the changing aesthetic and poetic dimensions of Chinese historical thinking, as the latter elegantly put into question the rationalist presumptions of "Western" historical scholarship.

One striking feature of the collection is the attention given to the aesthetic and emotional dimensions of education, and to the complicated role of the arts in particular. Thus, the chapter by de O, Martins, and Paz outlines a genealogy of the changing formation of the artist-as-subject in and of Portuguese education, while Lora offers an engaging account of how aesthetic sensibilities of "Mexicanicity" were crafted and disseminated through arts education to form a new national identity in early $20^{\text {th }}$ century Mexico. Dussel's contribution draws out implications of "the visual turn" in the history of education and cautions against taking visual images, and photographs in particular, as unproblematic representations of the real. In a thoughtprovoking chapter that started out as a biographical essay about Victorian school architect E.R. Robson, Burke and Grosvenor reflect on how historians might craft biographical accounts when only small details, or "body parts," can be known. Their paper makes visible historians' work of assemblage, organization, and imagination. Fendler's concluding chapter offers a reading of the previous chapters, reiterating and extending some of Popkewitz's discussion from the introduction. She organizes her reading of the chapters by contending that they attempt to dislodge four ghosts that haunt education history - the nation-state, the enlightenment, the archive, and chronology.

Popkewitz deploys a different conceptual device to organize his discussion of education history in the introductory chapter. Attending to "reason" as a "historical problem in the study of schooling," he borrows from Ian Hacking ${ }^{3}$ to talk about 
history as "styles of reason." This device allows him to "explore the principles that govern the forms of historical questions, its methods and meaning of the archive, and the modes of judgments as the narratives of history" (2). Distinctive "styles of reason" - Popkewitz identifies historicism and historicizing — is about more than different interpretations of the same data; it is about what comes to count as legitimate questions for historical inquiry; it is about decisions and procedures for what can be seen as data; and, it is about how the epistemological principles that shape and authorize historical accounts. On his reading, American (here meaning US) history of education has adopted an historicist style of reason based in positivism, founded on humanist principles, ahistorical notions of agency, and narratives of progress. For Popkewitz this "style" is problematic because it fails to historicize the conditions of possibility that produce particular phenomena as problems of education and as questions of historical inquiry. Historicism also fails to ask how some, but not all, ways of knowing, seeing, acting, and participating are made possible in education. And, while ostensibly committed to projects of justice and emancipation, critical histories of education that assume this "style of reason" unwittingly enclose their subjects, and their capacity to act, in ahistorical notions of agency.

As I suggested at the outset of this review, Popkewitz has posed these kinds of questions and critiques for a number of years in numerous publications, and he has done so in contexts of networks of graduate students and colleagues at the University of Wisconsin, Madison, as well as in Europe, South America, and China (and quite possibly elsewhere). Rethinking the History of Education is one of the products to come out of these networks and it seems apparent that an intense and lively set of conversations is taking place there. Although some of the chapters offer promising examples, it is less clear to this reader how other historians, and particularly those whose work might be critiqued in these pages, could be persuaded to join in those conversations. Adopting the style of the book we might ask about the terms that would govern education historians' speaking, acting, and participation. Would education historians have to denounce their attraction to the archive, to practices of detailed footnotes and citation, or, for the individual historian, to one's affinities for humanist notions of agency? Or, would it be possible to have a dialogue about those commitments, and to also bring into question the commitments that Popkewitz and colleagues are advancing? Where might Canadian historians of education want to situate themselves?

Apparently, there are formidable obstacles in the way of conversation and dialogue. The difficulty, from Popkewitz's perspective, is that although there are some American scholars who attend international meetings and who therefore are aware of international debates, in general "American historians" are "myopic" and provincial, and "...tend not to engage in broader intellectual debates in the field or recognize the comparative differences as related to theoretical, epistemological, and historical questions about the constitution of historical inquiry" (xiv). To make matters worse, he suggests that American historians of education (none of whom is named) tend to see international historiography as "merely" theory, to regard it as without "data" underpinning its narrative or interpretation, and to find it flawed because this international 
literature does not adhere to the methodological (positivist) principles of historical study. These are not promising grounds for dialogue.

Whether or not Canadian readers of HSE/RHÉ identify with Popkewitz or the American historians he critiques, they will find much that is of interest in the collection. Many of the chapters are certainly worth reading and to my reading some quite successfully bridge the divide that Popkewitz constructs. The questions they raise are both important and provocative, they are based on meticulous research, and they are very well written. As a minor point, several of the papers could have benefitted from careful copy-editing.

\section{Notes}

1 For example, Thomas S. Popkewitz, Cosmopolitanism and the Age of School Reform: Science, Education, and Making Society by Making the Child (New York: Routledge, 2008); Thomas S. Popkewitz and Marie Brennan eds., Foucault's Challenge: Discourse, Knowledge and Power in Education (New York: Teachers College Press, 1998); Thomas S. Popkewitz, Barry Franklin, and Miguel Pereyra eds., Cultural History and Education: Critical Essays on Knowledge and Schooling (New York: Routledge Falmer, 2001).

2 Thomas S. Popkewitz, "The Production of Reason and Power: Curriculum History and Intellectual Traditions," Journal of Curriculum Studies 29, no.2 (1997): 131-164.

3 Ian Hacking, "'Style' for Historians and Philosophers," Studies in the History and Philosophy of Science 23, no. 1 (1992): 1-20. 